\title{
Antioxidants Activity and Color Evaluation of Date Fruit of Selected Cultivars Commercially Available in the United States
}

\author{
Fahad Mohammed Al-Jasass, ${ }^{1}$ Muhammad Siddiq, ${ }^{2}$ and Dalbir S. Sogi ${ }^{3}$ \\ ${ }^{1}$ King Abdulaziz City for Science \& Technology, Life Science and Environment Research Institute, \\ National Center for Agricultural Technology, P.O. Box 6086, Riyadh 11442, Saudi Arabia \\ ${ }^{2}$ Food Science Consulting, Windsor, ON, Canada N9H $2 \mathrm{M} 4$ \\ ${ }^{3}$ Department of Food Science and Technology, Guru Nanak Dev University, Amritsar, India \\ Correspondence should be addressed to Fahad Mohammed Al-Jasass; aljasass@kacst.edu.sa
}

Received 2 April 2015; Accepted 28 May 2015

Academic Editor: C.-Y. Oliver Chen

Copyright (C) 2015 Fahad Mohammed Al-Jasass et al. This is an open access article distributed under the Creative Commons Attribution License, which permits unrestricted use, distribution, and reproduction in any medium, provided the original work is properly cited.

\begin{abstract}
Dates (Phoenix dactylifera L.) are nutrient-rich fruit consumed throughout the world, either directly or in several food products. Six commercially available date cultivars in the US were analyzed for total phenolics, antioxidant activity using ABTS, DPPH, FRAP, and ORAC assays, and instrumental color. Total phenolics content varied from 33 to $125 \mathrm{mg}$ GAE/100 g dry weight, with the highest in Barni (Saudi Arabia). Antioxidant values as determined by the ABTS in Deglet Nour (Algeria), Deglet Nour (California), Deglet Noor (Tunisia), Shahia (Tunisia), Barni (Saudi Arabia), and Khudri (Saudi Arabia) were 1300, 1047, 796, 452, 776, and 341 $\mu \mathrm{mol} \mathrm{TE/g}$ dry weight, respectively. Antioxidative properties as measure by DPPH, FRAP, and ORAC varied from 3.27 to 3.54, 3.29 to 5.22, and 189 to $243 \mu \mathrm{mol} \mathrm{TE} / \mathrm{g}$ dry basis, respectively. Fruit and pulp color of Deglet Nour (Algeria) was lighter whereas pulp of Barni (Saudi Arabia) was the darkest. Antioxidant values varied with different techniques used and also followed a different pattern than that of phenolics content.
\end{abstract}

\section{Introduction}

The date palm (Phoenix dactylifera L.) is grown in over 30 countries. Nutrient-rich dates are relished for their sweet, succulent, and exotic flavor. In recent years, dates have found acceptance among consumers in North America and European countries. Beside fresh consumption, this fruit is also processed into a wide variety of value-added products, such as dry dates, date paste, date syrup, date juice concentrate, date jam, date butter, date bars, date chutney, date relish, and date pickles, whereas date oil and date coffee are some of the byproducts produced from date seeds $[1,2]$.

Phytochemicals are naturally produced, nonnutritive, and bioactive compounds which are synthesized by plants for protection against external stresses and attack by pathogenic microorganisms [3]. Phytochemicals are reported to have various biological effects, such as antimutagenic, anticarcinogenic, antioxidant, antimicrobial, and anti-inflammatory [4].
These compounds can be divided into several classesphenolics, alkaloids, steroids, terpenes, and saponins. Phenolic compounds are characterized as having potent antioxidants and free radical scavengers, which can act as hydrogen donors, reducing agents, metal chelators, and singlet oxygen quenchers [5]. Phenolic compounds are active antioxidants playing an important role in neutralization of free radicals and decomposition of peroxides [6].

Date fruit has been shown to possess strong antioxidant activity among twenty-eight fruits commonly consumed in China [6]. Studies on various date fruit cultivars demonstrated a linear relationship between antioxidant activity and phenolic content [7]. Dates serve as a good source of natural antioxidants and could potentially be considered as functional food or ingredient $[8,9]$. Date fruit lowers the incidence of cancers, especially pancreatic cancer due to antitumor activity or antimutagenic properties, and boosts immune system [10-13]. Consumption of dates may also be 
beneficial in glycemic and lipid control in diabetic patients [14-16].

The objective of this study was to evaluate the total phenolics, antioxidant activity, and instrumental color of six commercially available date fruit cultivars in the United States.

\section{Materials and Methods}

2.1. Materials. Six commercially available date fruits, that is, Deglet Nour cultivated in California (DNC), Deglet Nour imported from Tunisia (DNT), Deglet Nour imported from Algeria (DNA), Khudri imported from Saudi Arabia (KSA), Barni imported from Saudi Arabia (BSA), and Shahia imported from Tunisia (SHT), were purchased from a local source in Lansing, MI, USA. The moisture content of cultivars was variable: DNC (24.1\%), DNT (26.4\%), DNA (25.3\%), KSA (23.78\%), BSA (20.4\%), and SHT (22.3\%). Therefore, all results are reported on dry weight basis to overcome the variation due to moisture content.

2.2. Sample Preparation. Samples were deseeded and crushed in Waring blender ( $20 \mathrm{~g}$ of date in $40 \mathrm{~mL}$ of distilled water); then, $2.5 \mathrm{~g}$ of the sample were taken in centrifuge tubes to which $20 \mathrm{~mL}$ of $80 \%$ methanol was added. The samples were stirred for $1 \mathrm{~h}$ at $200 \mathrm{rpm}$ in a water bath shaker, followed by centrifugation at $10,000 \times g$ for $10 \mathrm{~min}$. Supernatants were collected and the pellet was reextracted twice with $10 \mathrm{~mL} 80 \%$ methanol by vortexing and centrifugation at $10,000 \times g$ for $5 \mathrm{~min}$. Finally, all the supernatants were pooled and volume was made to $50 \mathrm{~mL}$ with $80 \%$ methanol.

2.3. Total Phenolics. Total phenolic contents were determined using the procedures described by Zieslin and Ben-Zaken [17]. Briefly, $0.5 \mathrm{~mL}$ of methanolic extract was mixed with $0.5 \mathrm{~mL}$ Folin-Ciocalteu reagent by annual shaking for 15$20 \mathrm{sec}$. After $3 \mathrm{~min}, 1 \mathrm{~mL}$ saturated sodium carbonate and $1 \mathrm{~mL}$ of distilled water were added. The reaction mixture was incubated in the dark at room temperature for $2 \mathrm{~h}$ and its absorbance was measured at $725 \mathrm{~nm}$ against deionized water using spectrophotometer. Results were expressed in mg gallic acid equiv. (GAE)/100 g dry weight (dw).

2.4. Antioxidant Capacity by DPPH. Analysis was carried out following the methods of Brand-Williams et al. [18]. The stock solution ( $24 \mathrm{mg} \mathrm{DPPH} / 100 \mathrm{~mL}$ methanol) was diluted with methanol to obtain an absorbance of 1.1 at $515 \mathrm{~nm}$ using spectrophotometer (Milton Roy, Warminster, PA, USA). $0.6 \mathrm{~mL}$ of the sample extracts, blank, or Trolox solution as standard was allowed to react with $3 \mathrm{~mL}$ of the DPPH working solution for 20 min under dark conditions. Then, the absorbance was taken at $515 \mathrm{~nm}$. Radical scavenging capacity was calculated from the absorbance of sample, blank, or Trolox solution as standard. The standard curve was prepared using Trolox as standard versus radical scavenging activity and the results were expressed in terms of micromole Trolox Equivalence $(\mu \mathrm{mol} \mathrm{TE}) / \mathrm{g}(\mathrm{dw})$.
2.5. Antioxidant Capacity by ABTS. ABTS radical cation $\left(\mathrm{ABTS}^{\circ+}\right)$ was produced by reacting ABTS stock solution $(7 \mathrm{mM})$ with potassium per sulfate $(2.45 \mathrm{mM})$ in the dark at room temperature for $12-16 \mathrm{~h}$. The $\mathrm{ABTS}^{\circ+}$ Solution was diluted with methanol $(80 \%)$ to an absorbance of 1.1 at $734 \mathrm{~nm}$. Diluted ABTS ${ }^{\circ+}$ solution $(3 \mathrm{~mL})$ was added to $30 \mu \mathrm{L}$ of sample or methanol for blank or Trolox solution as standard and the absorbance reading was taken at $30^{\circ} \mathrm{C}$ at $1 \mathrm{~min}$ interval up to $6 \mathrm{~min}$. The oxidation index at $6 \mathrm{~min}$ and then percent antioxidant activity were calculated. Antioxidant activity was plotted against the concentration of Trolox to get standard curve. The results of samples were computed as $\mu \mathrm{mol} \mathrm{TE} / \mathrm{g} \mathrm{dw}$.

2.5.1. Ferric Reducing Antioxidant Power (FRAP). The ferric reducing ability of dates extract was measured calorimetrically according to the method developed by Benzie and Strain [19]. The stock solutions included $300 \mathrm{mM}$ acetate buffer $(3.1 \mathrm{~g}$ $\mathrm{C} 2 \mathrm{H} 3 \mathrm{NaO} 2 \cdot 3 \mathrm{H} 2 \mathrm{O}$ and $16 \mathrm{~mL}$ C2H4O2) pH 3.6, $10 \mathrm{mM}$ TPTZ solution in $40 \mathrm{mM} \mathrm{HCl}$, and $20 \mathrm{mM} \mathrm{FeCl} 3 \cdot 6 \mathrm{H} 2 \mathrm{O}$ solution. The fresh experimental solution was prepared by mixing $2 \mathrm{~mL}$ acetate buffer, $2.5 \mathrm{~mL}$ TPTZ solution, and $2.5 \mathrm{~mL} \mathrm{FeCl} 3$ solution. A $3 \mathrm{~mL}$ FRAP reagent was taken in test tubes and $300 \mu \mathrm{L}$ of standard, blank, or sample was added. After $5 \mathrm{~min}$, the absorbance was recorded at $593 \mathrm{~nm}$. Standard curve was constructed using Trolox and the results were expressed in $\mu \mathrm{mol} \mathrm{TE} / 100 \mathrm{~g}$ dw.

2.6. Oxygen Radical Absorbance Capacity (ORAC). The ORAC assay for extracted dates samples was conducted on FLx800 Fluorescence Microplate Reader and Gen5 Data Analysis Software (BioTek Instruments Inc., Winooski, VT, USA). Exterior wells were filled with $300 \mu \mathrm{L}$ water; then, $150 \mu \mathrm{L}$ diluted fluorescein solution was added to all the experimental wells. For blank wells, $25 \mu \mathrm{L} 75 \mathrm{mM}$ sodium phosphate buffer ( $\mathrm{pH} 7.4$ ) was added. A $25 \mu \mathrm{L}$ of Trolox dilutions $(6.25-100 \mu \mathrm{M})$ was added to Trolox wells. A $25 \mu \mathrm{L}$ of the sample dilutions was added to sample wells. After incubation at $37^{\circ} \mathrm{C}$ for $30 \mathrm{~min}, 25 \mu \mathrm{L}$ AAPH was added to all the wells. The fluorescence was recorded for $3 \mathrm{~h}$ and results computed using software were expressed as $\mu \mathrm{mol} \mathrm{TE} / 100 \mathrm{~g}$ $\mathrm{dw}$ color measurement.

Color of whole and crushed dates was measured by Hunter Color Meter (Hunter Associates Lab, Reston, VA, USA). Instrument was calibrated using standard black and white tiles. Samples were placed in the standard cup and color values were recorded as $L$ (0, black; 100 , white), $a(-a$, greenness; $+a$, redness), and $b$ ( $-b$, blueness; $+b$, yellowness). Eight readings of each sample were taken from different sides.

2.7. Statistical Analysis. The data from three replicates were statistically analyzed using analysis of variance (ANOVA) following K. A. Gomez and A. A. Gomez [20]. The treatment means were compared using the least significant difference (LSD) at the 5\% level and were used to examine multiple comparisons between means according to Waller and Duncan [21]. All statistical analysis was performed using SAS software package, version 8.0 [22]. 
TABLE 1: Antioxidant activity of different date fruit cultivars as determined by ABTS, DPPH, FRAP, and ORAC assays.

\begin{tabular}{lcccc}
\hline \multirow{2}{*}{ Cultivars } & \multicolumn{3}{c}{ Antioxidant activity $(\mu$ mol Trolox equiv./g dry weight) } \\
& ABTS & DPPH & FRAP & ORAC \\
\hline Deglet Nour (Algeria) (DNA) & $1300.50 \pm 73.36^{\mathrm{a}}$ & $3.54 \pm 0.85^{\mathrm{a}}$ & $5.22 \pm 0.34^{\mathrm{a}}$ & $235.05 \pm 9.39^{\mathrm{a}}$ \\
Deglet Nour (California) (DNC) & $1047.34 \pm 61.20^{\mathrm{b}}$ & $3.33 \pm 0.86^{\mathrm{a}}$ & $3.80 \pm 0.77^{\mathrm{b}}$ & $189.11 \pm 14.61^{\mathrm{c}}$ \\
Deglet Nour (Tunisia) (DNT) & $795.74 \pm 59.36^{\mathrm{c}}$ & $3.50 \pm 0.88^{\mathrm{a}}$ & $4.65 \pm 0.83^{\mathrm{ab}}$ & $243.05 \pm 19.35^{\mathrm{a}}$ \\
Shahia (Tunisia) (SHT) & $451.80 \pm 32.19^{\mathrm{d}}$ & $3.27 \pm 0.81^{\mathrm{a}}$ & $3.70 \pm 0.47^{\mathrm{b}}$ & $202.49 \pm 17.74^{\mathrm{c}}$ \\
Barni (Saudi Arabia) (BSA) & $775.97 \pm 65.87^{\mathrm{c}}$ & $3.31 \pm 0.80^{\mathrm{a}}$ & $4.03 \pm 0.22^{\mathrm{ab}}$ & $224.28 \pm 17.77^{\mathrm{b}}$ \\
Khudri (Saudi Arabia) (KSA) & $341.38 \pm 71.79^{\mathrm{d}}$ & $3.35 \pm 0.78^{\mathrm{a}}$ & $3.29 \pm 0.41^{\mathrm{ab}}$ & $206 \pm 15.33^{\mathrm{b}}$ \\
\hline
\end{tabular}

Data is mean of three replicates \pm standard error. Means with different letters in the same column are significantly different at $p \leq 0.05$.

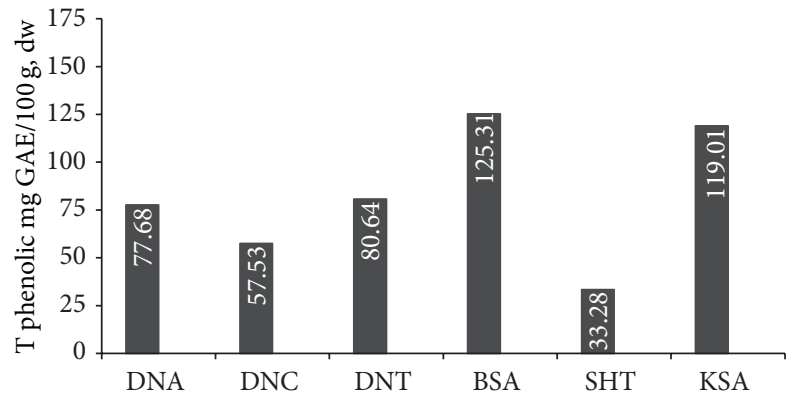

FIGURE 1: Total phenolic content of six date cultivars as gallic acid equivalent (GAE).

\section{Results and Discussion}

3.1. Total Phenolics. The total phenolics contents of six cultivars varied from 33 to $125 \mathrm{mg}$ GAE/100 g dw (Figure 1). The highest total phenolic content was observed in BSA whereas the lowest content was found in SHT. Wide variation was observed in the total phenolics contents among the date cultivars. ANOVA of total phenolics revealed significant differences ( $p \leq 0.05$ ) among the various date cultivars. Dates of the Deglet Nour cultivar (DNA, DNC, and DNT) from different countries showed significant difference $(p \leq$ $0.05)$, indicating the possible effect of location, weather, and agricultural practices. Al-Turki et al. [23] found that the range of total phenolics content in fresh dates was 225.0 to $507.0 \mathrm{mg}$ GAE/100 g, which was significantly higher than that observed in the present study. Similarly, Al-Farsi et al. [24] reported the total phenolics content of 172.0 to $246.0 \mathrm{mg}$ GAE/100 $\mathrm{g}$ fresh weight in selected Omani date varieties. In another study, AlFarsi et al. [9] reported the phenolics content to be in the range of 217.0 to $343.0 \mathrm{mg}$ GAE/100 $\mathrm{g}$ fresh weight. Mohamed et al. [25] reported total polyphenols content of 35.82 and $99.34 \mathrm{mg}$ GAE/100 $\mathrm{g}$ in six varieties of dates cultivated in Sudan. Wu et al. [26] reported that dates contain relatively higher amounts of total phenolics as compared to other fresh or dried fruits in a comparative study of total phenolics in different fruits. Present results indicated lower phenolics content as compared to the previous reports which might be due to the genetic makeup, agricultural practices, and analytical procedures.
3.2. Antioxidant Activity of Date Fruit. The results of the antioxidant assays showed that the antioxidant activity of date cultivars analyzed by ABTS, DPPH, FRAP, and ORAC varied to a large extent. Antioxidant values in terms of Trolox equivalent were low in DPPH assay than the highest observed by ABTS method. It indicated that components of the date cultivars reacted differently with chemicals involved in different antioxidant analytical protocols.

ABTS assay indicated high antioxidant activity that varied from 341 to $1300 \mu \mathrm{mol} \mathrm{TE} / \mathrm{g} \mathrm{dw}$ (Table 1). DNA showed about four-time higher antioxidant activity than KSA. Dates cultivars had more than $600 \mu \mathrm{mol} \mathrm{TE} / \mathrm{g} \mathrm{dw}$ activity except for KSA and SHT. Statistical analysis revealed that DNA had significantly higher antioxidant activity followed by DNC $(p \leq$ 0.05). The difference between DNT and BSA cultivars was nonsignificant in antioxidant activity. Similar observations were noted between KSA and SHT cultivars. DPPH assay revealed the antioxidant values in the range of 3.27-3.54 $\mu \mathrm{mol}$ TE/g dw. Statistical analysis showed that the antioxidant values by DPPH method did not vary significantly $(p>0.05)$ among the six cultivars. It indicated that DPPH decolorizing reaction was not supported by date constituents and thus showed a little activity.

Antioxidant activity assayed by FRAP showed that values varied from 3.29 to $5.22 \mu \mathrm{mol} \mathrm{TE} / \mathrm{g}$ dw. DNA cultivar also exhibited the highest activity while KSA showed the minimum activity. The general pattern of antioxidant activity was comparable to ABTS but values were quite low. Statistical analysis showed significant difference $(p \leq 0.05)$ in FRAP values among the six cultivars.

The ORAC values of six date cultivars varied from 189 to $243 \mu \mathrm{mol} \mathrm{TE} / \mathrm{g}$ with higher activity in DNA and DNT. The lowest in ORAC values were observed in DNC and SHT. Statistical analysis showed that ORAC values varied significantly among the cultivars $(p \leq 0.05)$.

The ORAC values were higher than DPPH and FRAP but lower than ABTS values. The variations in antioxidant activities of different date cultivars were expected due to variation in agroclimatic conditions, variety, and country of origin. In addition, temperature, relative humidity, maturity, and processing can have a significant impact on phytochemicals profile of the date fruit $[8,27,28]$. The antioxidant values measured by different techniques did not give similar results. ABTS and FRAP analysis indicated that DNA had the highest 
TABLE 2: Hunter color values of whole dates and date paste from different cultivars.

\begin{tabular}{|c|c|c|c|c|c|c|}
\hline \multirow{2}{*}{ Date cultivars } & \multicolumn{3}{|c|}{ Whole fruit } & \multicolumn{3}{|c|}{ Ground fruit (paste) } \\
\hline & $L$ & $a$ & $b$ & $L$ & $a$ & $b$ \\
\hline Deglet Nour (Algeria) (DNA) & $19.35 \pm 2.59^{\mathrm{abc}}$ & $5.04 \pm 0.93^{\mathrm{a}}$ & $4.54 \pm 0.62^{\mathrm{a}}$ & $42.13 \pm 1.14^{\mathrm{b}}$ & $3.98 \pm 0.49^{c}$ & $9.71 \pm 0.47^{\mathrm{b}}$ \\
\hline Deglet Nour (California) (DNC) & $21.06 \pm 0.85^{\mathrm{a}}$ & $4.28 \pm 1.35^{\mathrm{a}}$ & $4.21 \pm 0.45^{\mathrm{ab}}$ & $47.05 \pm 1.37^{\mathrm{a}}$ & $3.89 \pm 1.43^{\mathrm{c}}$ & $11.50 \pm 3.51^{\mathrm{b}}$ \\
\hline Deglet Nour (Tunisia) (DNT) & $18.40 \pm 0.61^{b c}$ & $4.35 \pm 0.44^{\mathrm{a}}$ & $3.61 \pm 0.43^{\mathrm{b}}$ & $37.58 \pm 3.68^{\mathrm{c}}$ & $6.15 \pm 1.66^{\mathrm{ab}}$ & $8.63 \pm 1.68^{\mathrm{b}}$ \\
\hline Shahia (Tunisia) (SHT) & $20.19 \pm 0.34^{\mathrm{ab}}$ & $4.51 \pm 1.34^{\mathrm{a}}$ & $3.68 \pm 0.70^{\mathrm{b}}$ & $45.46 \pm 1.04^{\mathrm{ab}}$ & $4.44 \pm 0.20^{\mathrm{bc}}$ & $10.85 \pm 0.33^{\mathrm{b}}$ \\
\hline Barni (Saudi Arabia) (BSA) & $19.26 \pm 1.36^{c}$ & $1.80 \pm 0.37^{\mathrm{b}}$ & $2.20 \pm 0.35^{\mathrm{c}}$ & $37.56 \pm 4.30^{c}$ & $5.85 \pm 2.14^{\mathrm{abc}}$ & $9.35 \pm 2.83^{\mathrm{b}}$ \\
\hline Khudri (Saudi Arabia) (KSA) & $17.81 \pm 0.41^{c}$ & $4.81 \pm 0.81^{\mathrm{a}}$ & $2.58 \pm 0.09^{c}$ & $42.84 \pm 1.44^{\mathrm{b}}$ & $6.86 \pm 1.56^{\mathrm{bc}}$ & $15.23 \pm 3.82^{\mathrm{a}}$ \\
\hline
\end{tabular}

Data is mean of eight replicates \pm standard error. Means with different letters in the same column are significantly different at $p \leq 0.05$.

antioxidant activity while ORAC analysis showed that DNT and DNA had the highest antioxidant activity.

The antioxidant activity data is not supported by the total phenolics content as reported by some researchers. Study also indicated that the composition of the date cultivars varied significantly. Moreover, dates participate in reaction involving antioxidant estimation differently in different techniques used.

Al-Turki et al. [23] reported that the antioxidant activity measured by ABTS was higher than that measured by $\mathrm{DPPH}$. Their results support the present findings where the antioxidant activity values of DPPH were lower than the ABTS values.

3.3. Date Fruit and Paste Color. Color is the important parameter affecting the consumer acceptability. It is also an important quality parameter in commercial date fruits. The results of color measurement of whole fruit dates and date paste of different cultivars, in terms of Hunter $L, a$, and $b$ values, are presented in Table 2. Measuring of whole date fruits color is useful for the comparison between different date cultivars and for quality control of processed date products in the international trade. In whole date fruits, Hunter $L$ values varied in the range of 18.44 to 21.06 among the cultivars. Higher $L$ values indicate "lighter" color; thus, KSA had dark color whereas DNC had light color. Statistical analysis showed a significant difference $(p \leq 0.05)$ in $L$ values of whole fruit. The Hunter color $L$ values for date pastes showed a similar trend but were in the range of 37.5747.05. The $L$ values of the paste increased indicating that color became lighter. Among the cultivars BSA and DNT had dark color whereas DNC had lighter color.

The Hunter color $a$ values, of the whole dates ranged from 1.8 to 5.04. Statistical analysis showed a significant $(p \leq$ $0.05)$ difference of " $a$ " value in whole date. Hunter values of paste varied from 3.9 to 6.9. None of the dates or pastes having Hunter values were in the negative $(-)$ range, which reflected the absence of any greenish tint. Hunter $b$ values varied from 2.20 to 4.53 in whole fruits and from 8.63 to 15.23 in ground paste of date. The Hunter color $b$ values of dates were observed to be high for DNA whole fruit while being low for BSA. Similarly, KSA cultivars had the highest $a$ value whereas DNT had the lowest. Measuring the color of date fruit paste is useful in comparing different dates. Overall, the difference in color is mainly due to the genetic variability [27].
Hasnaoui et al. [29] evaluated the fruit color for twentyseven of date palm cultivars collected from Moroccan oases at Tamar stage (fully ripened) and found the $L$ values in the range of 12.12 to $38.93, a$ values in the range of 1.35 to 15.29 , and $b$ in the range of 0.86 to 35.12 .

\section{Conclusion}

Characterization of date fruit for antioxidant properties can expand this fruit's consumption, as consumers are increasingly looking for healthy food. Barni and Khudri cultivars had relatively higher phenolics content than other four cultivars. With respect to assessing antioxidant capacity, the ABTS method gave higher antioxidant values than other three methods used in this study. Deglet Nour from Algeria has higher antioxidant properties than others cultivars. Light colored dates are considered better; Deglet Nour from California showed a better color with higher $L$ values. Based on the results of this study, it can be concluded that date cultivars had medium phenolic contents and significant antioxidant activity. However, relationship between phenolic contents and the antioxidant activity of the respective date cultivars could not be established conclusively. Our work adds expanded scientific information on antioxidant analysis of different cultivars. We used different methods to measure the antioxidants capacity of dates.

\section{Conflict of Interests}

The authors declare that there is no conflict of interests regarding the publication of this paper.

\section{Acknowledgments}

This research was supported financially by the King Abdulaziz City for Science \& Technology (KACST) through the Summer Grant for the Ph.D. Degree Staff. Thanks are extended to Dr. Kirk Dolan (Michigan State University) for allowing the use of his lab equipment for analyzing antioxidant activity.

\section{References}

[1] D. Huntrods, "Date profile," Agricultural Marketing Resource Center Bulletin, USDA, Washington, DC, USA, 2011. 
[2] P. Vijayanand and S. G. Kulkarni, "Processing of dates into value-added products," in Dates Production, Processing, Food and Medicinal Values, A. Manickavasagan, M. Mohamed Essa, and E. Sukumar, Eds., pp. 255-264, CRC Press, Boca Raton, Fla, USA, 2012.

[3] Y.-L. Chew, J.-K. Goh, and Y.-Y. Lim, "Assessment of in vitro antioxidant capacity and polyphenolic composition of selected medicinal herbs from Leguminosae family in Peninsular Malaysia," Food Chemistry, vol. 116, no. 1, pp. 13-18, 2009.

[4] G.-C. Yen and C.-L. Hsieh, "Antioxidant activity of extracts from Du-zhong (Eucommia ulmoides) toward various lipid peroxidation models in vitro," Journal of Agricultural and Food Chemistry, vol. 46, no. 10, pp. 3952-3957, 1998.

[5] G. C. Yen, P. D. Duh, and C. L. Tsai, "Relationship between antioxidant activity and maturity of peanut hulls," Journal of Agricultural and Food Chemistry, vol. 41, no. 1, pp. 67-70, 1993.

[6] C. Guo, J. Yang, J. Wei, Y. Li, J. Xu, and Y. Jiang, "Antioxidant activities of peel, pulp and seed fractions of common fruits as determined by FRAP assay," Nutrition Research, vol. 23, no. 12, pp. 1719-1726, 2003.

[7] A. A. A. Allaith, "Antioxidant activity of Bahraini date palm (Phoenix dactylifera L.) fruit of various cultivars," International Journal of Food Science and Technology, vol. 43, no. 6, pp. 10331040, 2008.

[8] M. Al-Farsi, C. Alasalvar, M. Al-Abid, K. Al-Shoaily, M. Al-Amry, and F. Al-Rawahy, "Compositional and functional characteristics of dates, syrups, and their by-products," Food Chemistry, vol. 104, no. 3, pp. 943-947, 2007.

[9] M. Al-Farsi, A. Morris, and M. Baron, "Functional properties of omani dates (Phoenix dactylifera L.)," Acta Horticulturae, vol. 736, pp. 479-487, 2007.

[10] P. K. Vayalil, "Antioxidant and antimutagenic properties of aqueous extract of date fruit (Phoenix dactylifera L. Arecaceae)," Journal of Agricultural and Food Chemistry, vol. 50, no. 3, pp. 610-617, 2002.

[11] O. Ishurd and J. F. Kennedy, "The anti-cancer activity of polysaccharide prepared from Libyan dates (Phoenix dactylifera L.)," Carbohydrate Polymers, vol. 59, no. 4, pp. 531-535, 2005.

[12] A. Mansouri, G. Embarek, E. Kokkalou, and P. Kefalas, "Phenolic profile and antioxidant activity of the Algerian ripe date palm fruit (Phoenix dactylifera)," Food Chemistry, vol. 89, no. 3, pp. 411-420, 2005.

[13] J. A. Duke, Handbook of Phytochemical of GRAS Herbs and Other Economic Plants, 1992.

[14] S. A. A. Jassim and M. A. Naji, "In vitro evaluation of the antiviral activity of an extract of date palm (Phoenix dactylifera 1.) pits on a pseudomonas phage," Evidence-Based Complementary and Alternative Medicine, vol. 7, no. 1, pp. 57-62, 2010.

[15] C. J. Miller, E. V. Dunn, and I. B. Hashim, "Glycemic index of 3 varieties of dates," Saudi Medical Journal, vol. 23, no. 5, pp. 536$538,2002$.

[16] C. J. Miller, E. V. Dunn, and I. B. Hashim, “The glycaemic index of dates and date/yoghurt mixed meals. Are dates 'the candy that grows on trees'?" European Journal of Clinical Nutrition, vol. 57, no. 3, pp. 427-430, 2003.

[17] N. Zieslin and R. Ben-Zaken, "Peroxidase activity and presence of phenolic substances in peduncles of rose flower," Plant Physiology and Biochemistry, vol. 31, no. 3, pp. 333-339, 1993.

[18] W. Brand-Williams, M. E. Cuvelier, and C. Berset, "Use of a free radical method to evaluate antioxidant activity," LWT-Food Science and Technology, vol. 28, no. 1, pp. 25-30, 1995.
[19] I. F. F. Benzie and J. J. Strain, "Ferric reducing/antioxidant power assay: direct measure of total antioxidant activity of biological fluids and modified version for simultaneous measurement of total antioxidant power and ascorbic acid concentration," Methods in Enzymology, vol. 299, pp. 15-27, 1999.

[20] K. A. Gomez and A. A. Gomez, Statistical Procedures for Agricultural Research, John Wiley \& Sons, Ames, Iowa, USA, 2nd edition, 1984.

[21] SAS, SAS for Windows, SAS User's Guide: Statistics, Version 8.0e, SAS Institute, Cary, NC, USA, 2001.

[22] R. A. Waller and D. B. Duncan, "A Bayes rule for the symmetric multiple comparisons problem," Journal of the American Statistical Association, vol. 64, pp. 1484-1499, 1969.

[23] S. Al-Turki, M. A. Shahba, and C. Stushnoff, "Diversity of antioxidant properties and phenolic content of date palm (Phoenix dactylifera L.) fruits as affected by cultivar and location," Journal of Food, Agriculture and Environment, vol. 8, no. 1, pp. 253-260, 2010.

[24] M. Al-Farsi, C. Alasalvar, A. Morris, M. Baron, and F. Shahidi, "Comparison of antioxidant activity, anthocyanins, carotenoids, and phenolics of three native fresh and sun-dried date (Phoenix dactylifera L.) varieties grown in Oman," Journal of Agricultural and Food Chemistry, vol. 53, no. 19, pp. 75927599, 2005.

[25] R. M. A. Mohamed, A. S. M. Fageer, M. M. Eltayeb, and I. A. M. Ahmed, "Chemical composition, antioxidant capacity, and mineral extractability of Sudanese date palm (Phoenix dactylifera L.) fruits," Food Science \& Nutrition, vol. 2, no. 5, pp. 478489, 2014.

[26] X. Wu, G. R. Beecher, J. M. Holden, D. B. Haytowitz, S. E. Gebhardt, and R. L. Prior, "Lipophilic and hydrophilic antioxidant capacities of common foods in the United States," Journal of Agricultural and Food Chemistry, vol. 52, no. 12, pp. 4026-4037, 2004.

[27] F. Biglari, A. F. M. AlKarkhi, and A. M. Easa, "Antioxidant activity and phenolic content of various date palm (Phoenix dactylifera) fruits from Iran," Food Chemistry, vol. 107, no. 4, pp. 1636-1641, 2008.

[28] J. Gross, O. Haber, and R. Ikan, “The carotenoid pigments of the date," Scientia Horticulturae, vol. 20, no. 3, pp. 251-257, 1983.

[29] M. Hasnaoui, A. Elhoumaizi, A. Hakkou, B. Wathelet, and M. Sindic, "Physico-chemical characterization, classification and quality evaluation of date palm fruits of some Moroccan cultivars," Journal of Scientific Research, vol. 3, no. 1, pp. 139-149, 2011. 

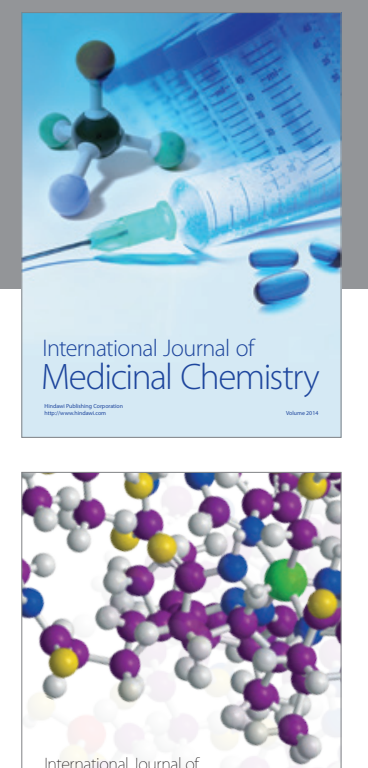

\section{Carbohydrate} Chemistry

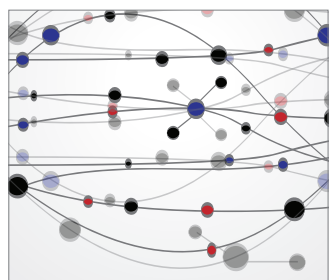

The Scientific World Journal
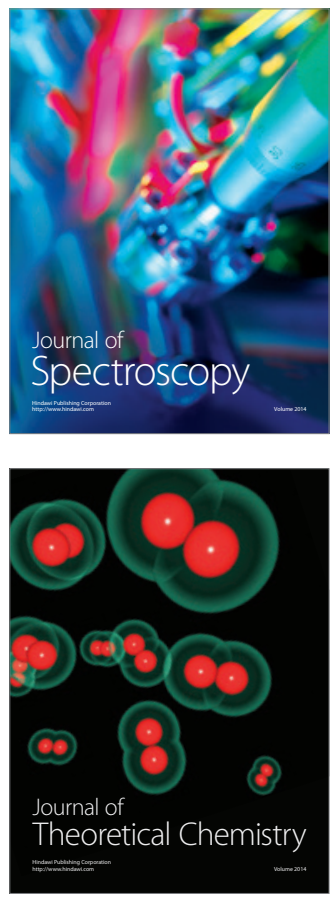
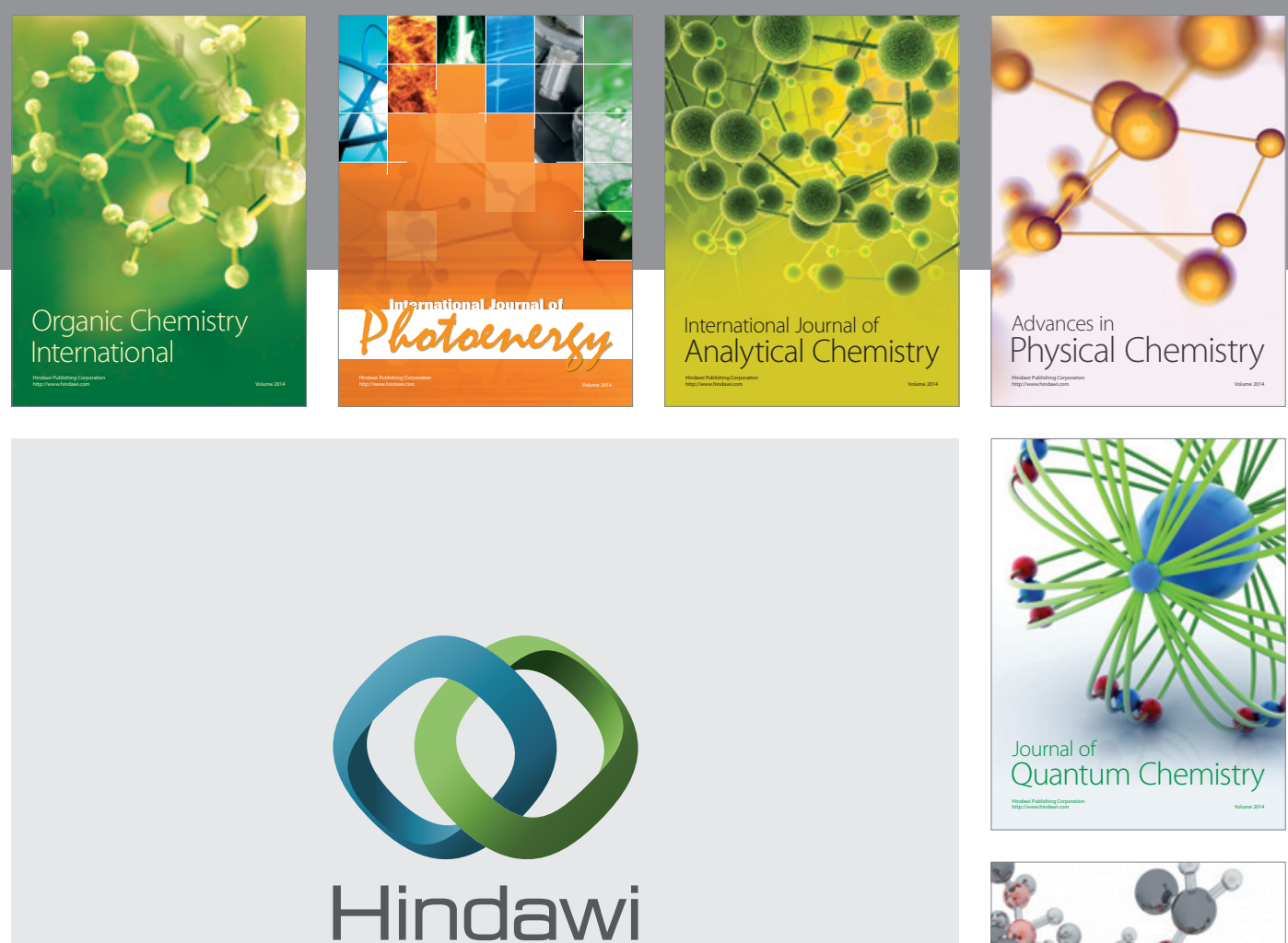

Submit your manuscripts at

http://www.hindawi.com

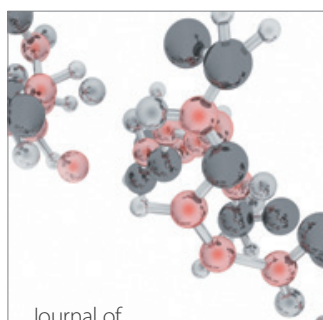

Analytical Methods

in Chemistry

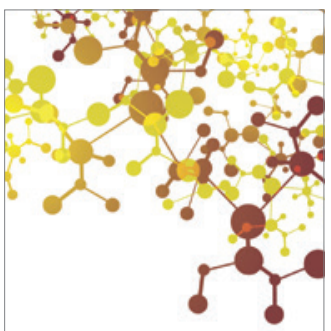

Journal of

Applied Chemistry

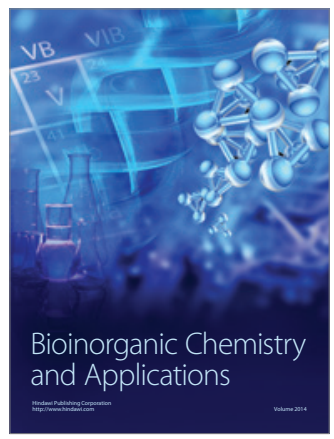

Inorganic Chemistry
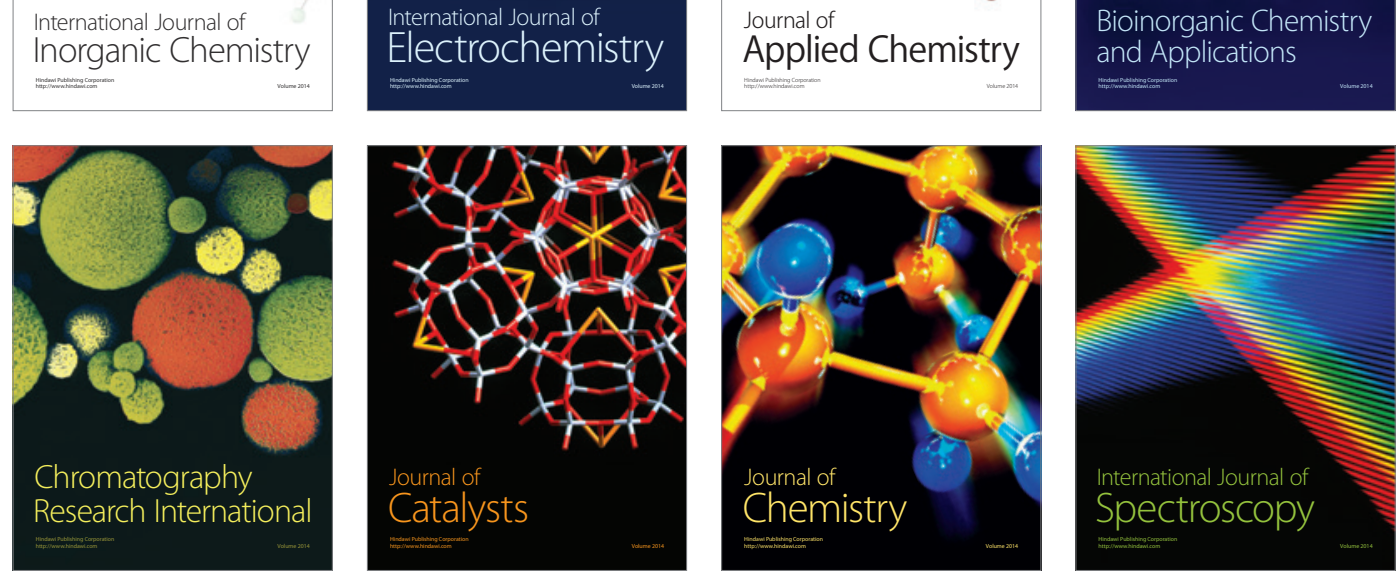